\title{
ANALISIS KINERJA RUAS JALAN RAYA SINGOSARI KABUPATEN MALANG
}

\author{
Agustina P F Seran \\ Sugiyanto dan Pranoto
}

\begin{abstract}
Abstrak:Peningkatan volume lalu lintas jika tidak diimbangi dengan kinerja jaringan jalan yang baik akan menyebabkan terjadinya kemacetan. Dengan mengetahui tingkat pelayanan jalan saat ini, dapat ditentukan penanganan yang tepat untuk meningkatkan kinerja jalan.Tujuan penelitian : (1) Mengetahui karakteristik lalu lintas Jalan Raya Singosari; (2) Mengetahui kinerja ruas Jalan Raya Singosari; (3) Mengetahui kinerja ruas Jalan Raya Singosari setelah diterapkan alternatif penanganan masalah lalu lintas yang terjadi.Metode dilakukan dengan survei geometri jalan, survei volume kendaraan, survei kecepatan kendaraan, dan survei hambatan samping. Analisis data menggunakan Manual Kapasitas Jalan Indonesia 1997. Penelitian dilakukan pada hari Minggu, Senin, dan Selasa pukul 06.00-22.00.Hasil penelitian : (1) Karakteristik lalu lintas pada ruas Jalan Raya Singosari arah Lawang, volume kendaraan tertinggi sebesar 2561,8 smp/jam pada pukul 16.30 - 17.30, kecepatan rata-rata $26,31 \mathrm{~km} / \mathrm{jam}$, dan kepadatan rata-rata $155,99 \mathrm{smp} / \mathrm{km}$. Sedangkan untuk arah Malang, volume kendaraan tertinggi sebesar 2455,4 smp/jam pada pukul $16.00-17.00$, kecepatan ratarata $29,34 \mathrm{~km} / \mathrm{jam}$, dan kepadatan rata-rata $132,35 \mathrm{smp} / \mathrm{km}$. (2) Tingkat pelayanan rata-rata pada ruas Jalan Raya Singosari berada di rentang D dan E dengan tingkat pelayanan pada jam puncak adalah F. (3) Dengan alternatif pelebaran jalan dalam bentuk penambahan 1 lajur, tingkat pelayanan menjadi lebih baik di kelas C. Sedangkan dengan alternatif penerapan jalan tanpa hambatan samping, tingkat pelayanan menjadi lebih baik di kelas $\mathrm{C}$ dan $\mathrm{D}$.
\end{abstract}

Kata-kata kunci: kinerja jalan, tingkat pelayanan, jalan raya singosari

\begin{abstract}
An increase in traffic volume if not balanced with good road network performance will cause congestion. By knowing the current level of road service, it can be determined the appropriate treatment to improve road performance. Research objectives: (1) Knowing the traffic characteristics of Singosari Highway; (2) Knowing the performance of the Singosari Highway section; (3) Knowing the performance of the Singosari Highway section after implementing alternative handling of traffic problems. The method is carried out by surveying the road geometry, surveying the volume of vehicles, surveying the speed of vehicles, and surveying side friction. Data analysis used the Indonesian Road Capacity Manual 1997. The study was conducted on Sundays, Monday and Tuesday from 06.00-22.00. The results of the study: (1) Traffic characteristics on Jalan Raya Singosari in the direction of Lawang, the highest vehicle volume was 2561.8 pcu hours at 16.30 - 17.30, average speed of $26.31 \mathrm{~km} / \mathrm{hour}$, and an average density of $155.99 \mathrm{pcu} / \mathrm{km}$. Meanwhile, for Malang direction, the highest vehicle volume was $2455.4 \mathrm{pcu} / \mathrm{hour}$ at 16.00-17.00, the average speed was $29.34 \mathrm{~km} / \mathrm{hour}$, and the average density was $132.35 \mathrm{pcu} / \mathrm{km}$. (2) The average service level on Jalan Raya Singosari is in the range $D$ and $E$ with the level of service at peak hours is $F$. (3) With the alternative of road widening in the form of adding 1 lane, the service level is better in class $C$. Whereas with the alternative of implementing roads without side obstacles, the level of service is better in classes $C$ and $D$.
\end{abstract}

Keywords: road performance, service level, Jalan Raya Singosari

Agustina P F Seran adalah Alumni Jurusan Teknik Sipil Fakultas, Email: faridaseran@gmail.com; Sugiyanto dan Pranoto adalah Dosen Jurusan Teknik Sipil Fakultas Teknik UM; Jalan Semarang No.5 Malang 65145; Email: sugiyanto.ft@um.ac.id, kangnoto20@gmail.com 


\section{PENDAHULUAN}

Kabupaten Malang menjadi pintu masuk ke Kota Malang yang juga dikenal sebagai kota pendidikan, kota pelajar, dan kota pariwisata. Hal tersebut berpengaruh terhadap peningkatan kebutuhan transportasi keluar-masuk Kota Malang. Transportasi dari maupun menuju Kota Malang melalui Kabupaten Malang menjadi semakin meningkat seiring dengan peningkatan jumlah penduduk. Pemilihan moda transportasi pribadi juga lebih diminati daripada menggunakan moda transportasi umum. Hal tersebut berdampak pada peningkatan volume kendaraan di beberapa titik di Kabupaten Malang.

Peningkatan volume lalu lintas jika tidak diimbangi dengan kinerja jaringan jalan yang baik dapat menimbulkan permasalahan lalu lintas seperti kemacetan. Beberapa penyebab kemacetan yaitu: volume kendaraan tinggi, kapasitas jalan rendah, perilaku pengendara yang kurang baik, dan adanya aktivitas di samping jalan yang mengganggu arus lalu lintas. Salah satu titik kemacetan di Kabupaten Malang adalah ruas Jalan Raya Singosari yang berada di Kecamatan Singosari. Jalan Raya Singosari termasuk kategori jalan nasional dan jalan arteri primer (SK Gubernur Jatim, 2016).

Menurut Dinas Perhubungan Komunikasi dan Informasi Kabupaten Malang, terjadi peningkatan lalu lintas harian di ruas jalan Lawang-Singosari. Pada tahun 2015, volume kendaraan melintas mencapai 121.871 kendaraan per hari. Volume tersebut meningkat pada tahun 2016 menjadi 134.058 kendaraan per hari. Jalan Raya Singosari STA 77-78 merupakan titik kemac- etan tiap harinya terutama pada jam sibuk.

Salah satu faktor yang menyebabkan kemacetan selain peningkatan volume lalu lintas adalah penurunan kapasitas jalan yang disebabkan oleh hambatan samping diantaranya: pejalan kaki, pemberhentian angkutan umum dan kendaraan lain serta kendaraan keluar masuk dari lahan samping jalan (Oglesby, 1999).

Adapun beberapa sumber hambatan samping yang terjadi di ruas Jalan Raya Singosari STA 78 adalah adanya kegiatan perdagangan di Pasar Singosari sehingga banyak pejalan kaki dan penyeberang jalan dan beberapa titik di sekitar Pasar Singosari tidak menyediakan kawasan parkir sendiri, sehingga area parkir memakai badan jalan. Menurut hasil penelitian Putra dkk (2011), kegiatan pasar mempunyai pengaruh terhadap kinerja jalan ditunjukkan dengan penurunan kapasitas dan derajat kejenuhan. Hadi (2004) menyatakan bahwa hasil penelitian kegiatan pasar mempunyai pengaruh terhadap kinerja jalan sebagai jalan arteri ditunjukkan dengan rendahnya kecepatan kendaraan ringan hingga 24,79 km/jam.

Kegiatan pejalan kaki juga berpengaruh secara signifikan terhadap kinerja jalan. Menurut Setyawan (2004), berdasarkan perhitungan dengan MKJI 1997, kapasitas jalan menurun dari semula $3457 \mathrm{smp} /$ jam menjadi $2550 \mathrm{smp} /$ jam akibat adanya kegiatan pejalan kaki. Selain pejalan kaki, keberadaan parkir yang menggunakan badan jalan juga dapat mengurangi kapasitas jalan. Aktifitas suatu pusat kegiatan akan menimbulkan aktifitas parkir kendaraan yang berpotensi menimbulkan berbagai masalah seperti parkir yang memanfaatkan badan jalan (Ansyori, 2003). Terjadinya proses naik 
turun penumpang moda transportasi umum seperti angkutan umum dan bus antar kota di sepanjang badan jalan dan proses keluar masuknya truk pengangkut barang dari sisi jalan karena adanya beberapa industri di jalan tersebut dapat mengurangi kapasitas jalan. Menurut Yunianta (2006), kecepatan kendaraan cenderung lambat akibat adanya manuver kendaraan parkir ketika terjadi akses keluar masuk kendaraan pada sisi jalan dengan kecepatan kendaraan turun hingga 23\%. Permasalahan tersebut menyebabkan lebar efektif jalan berkurang dan kecepatan menjadi rendah sehingga berdampak pada kemacetan lalu lintas.

Dengan peningkatan volume harian yang terjadi tiap tahunnya tidak diimbangi kapasitas jalan yang memadai dan aktivitas sisi jalan yang berpotensi meningkatkan jumlah hambatan samping, ada kecenderungan arus lalu lintas pada Jalan Raya Singosari menjadi tidak stabil dan terjadi kemacetan yang dapat menyebabkan penurunan kinerja jalan. Sehingga perlu dilakukan penelitian lebih lanjut untuk mengetahui bagaimana kinerja jalan tersebut saat ini dan penyelesaian terhadap masalah kemacetan yang terjadi. Salah satunya adalah dengan penilaian tingkat pelayanan (Level of Service) yang dapat digunakan untuk menunjukkan kinerja jalan tersebut (MKJI, 1997). Dengan mengetahui kinerja jalan tersebut pada saat ini, diharapkan nantinya dapat ditentukan penanganan yang tepat untuk meningkatkan kinerja jalan tersebut.

\section{METODE}

Data primer didasarkan pada hasil survei yaitu data geometri jalan, data volume kendaraan, data kecepatan kendaraan ringan dan data hambatan samping. Pengambilan data dilakukan di Jalan Raya Singosari STA 78. Waktu pengambilan data dilakukan pada hari Minggu, Senin dan Selasa selama 16 jam dari pukul 06.00 - 22.00 WIB. Interval waktu pengamatan adalah lima belas menit.

Peralatan yang dibutuhkan untuk pengambilan data yaitu form survei, kamera CCTV untuk merekam jumlah kendaraan yang melintas, meteran, stopwatch dan cat semprot. Surveyor dalam penelitian ini berjumlah 8 orang terdiri dari 2 surveyor geometri jalan, 2 surveyor kecepatan kendaraan dan 4 surveyor hambatan samping.

Pengambilan data geometri jalan dilakukan dengan oengukuran langsung menggunakan meteran. Data berupa jumlah lajur, panjang dan lebar jalan, lebar median, bahu jalan dan trotoar. Pengambilan data volume kendaraan dilakukan dengan menghitung semua kendaraan (sepeda motor, kendaraan ringan dan kendaraan berat) yang melewati garis pengamatan pada ruas Jalan Raya Singosari STA 78 dengan perekaman menggunakan CCTV. Data kecepatan yang digunakan adalah kecepatan tempuh rata-rata uang dihitung dengan membagi panjang kedua titik pengamatan dan waktu tempuh. Panjang penggal yang digunakan dalam penelitian ini adalah 25 meter karena perkiraan kecepatan rata-rata adalah $<40 \mathrm{~km} / \mathrm{jam}$. Jumlah sampel yang diambil adalah 5 sampel kendaraan ringan per 15 menit. Pengambilan data hambatan samping dilakukan dengan menghitung jumlah kejadian tiap tipe hambatan sepanjang 200 meter pada kedua sisi segmen jalan. Jenis 
hambatan yang disurvei adalah pejalan kaki, penyeberang jalan di badan jalan, kendaraan parkir/berhenti di badan jalan, kendaraan lambat/kendaraan tak bermotor dan kendaraan keluar masuk dari lahan samping jalan.

Pengolahan data pengamatan pada penelitian ini menggunakan analisis deskriptif dengan pendekatan kuantitatif. Analisis dilakukan dengan metode dari Manual Kapasitas Jalan Indonesia tahun 1997 dengan bantuan program Microsoft Excel.
HASIL

\section{Geometri Jalan Raya Singosari}

Data berupa jumlah lajur, jumlah arah, lebar jalan, ada tidaknya median, bahu jalan dan trotoar. Hasil pengamatan geometri Jalan Raya Singosari ditunjukkan pada Tabel 1.

\section{Volume Kendaraan}

Hasil pengamatan volume kendaraan tertinggi dan rata-rata harian pada ruas Jalan Raya Singosari arah Lawang ditunjukkan pada Tabel 2 dan Tabel 3 .

Tabel 1. Data Geometri Jalan Raya Singosari

\begin{tabular}{cccccc}
\hline Ruas Jalan & Tipe Jalan & $\begin{array}{c}\text { Lebar Ja- } \\
\text { lan }(\mathbf{m})\end{array}$ & Bahu/Kerb & $\begin{array}{c}\text { Median } \\
(\mathbf{m})\end{array}$ & $\begin{array}{c}\text { Trotoar } \\
(\mathbf{m})\end{array}$ \\
\cline { 1 - 4 } Arah Lawang & \multirow{2}{*}{ 4/2 D } & 7,00 & - & \multirow{2}{*}{1,5} & $\frac{2,0 \mathrm{~m}}{2,0 \mathrm{~m}}$ \\
\cline { 1 - 3 } & & 7,00 & - & &
\end{tabular}

Tabel 2. Data Volume Kendaraan Tertinggi di Jalan Raya Singosari Arah Lawang

\begin{tabular}{|c|c|c|c|c|c|}
\hline \multirow[t]{2}{*}{ Hari } & \multirow[t]{2}{*}{ Pukul } & \multicolumn{3}{|c|}{$\begin{array}{l}\text { Jumlah kendaraan (smp/ } \\
\text { jam) }\end{array}$} & \multirow{2}{*}{$\begin{array}{l}\text { Volume Tertingg } \\
\text { (smp/jam) }\end{array}$} \\
\hline & & MC & LV & $\mathrm{HV}$ & \\
\hline Minggu & $16.30-17.30$ & 784 & 1305 & 472,8 & 2561,8 \\
\hline Senin & $14.30-15.30$ & 679 & 1310 & 445,2 & 2434,2 \\
\hline Selasa & $14.30-15.30$ & 685,25 & 1297 & 450 & 2432,25 \\
\hline
\end{tabular}

Tabel 3. Data Volume Kendaraan Rata-rata Harian di Jalan Raya Singosari Arah Lawang

\begin{tabular}{ccccc}
\hline \multirow{2}{*}{ Hari } & \multicolumn{2}{c}{ Jumlah kendaraan rata-rata harian (smp/jam) } & Volume Rata-rata Harian \\
\cline { 2 - 4 } & $\mathbf{M C}$ & $\mathbf{L V}$ & $\mathbf{H V}$ & $(\mathbf{s m p / j a m )}$ \\
\hline Minggu & 578,16 & 1161 & 410,7 & 2149,85 \\
\hline Senin & 561,3 & 1135,1 & 392,48 & 2088,89 \\
\hline Selasa & 567,88 & 1104,6 & 383,33 & 2055,82 \\
\hline
\end{tabular}

Data volume kendaraan (smp/jam) ruas Jalan Raya Singosari Arah Lawang ditunjukkan pada Gambar 2. 


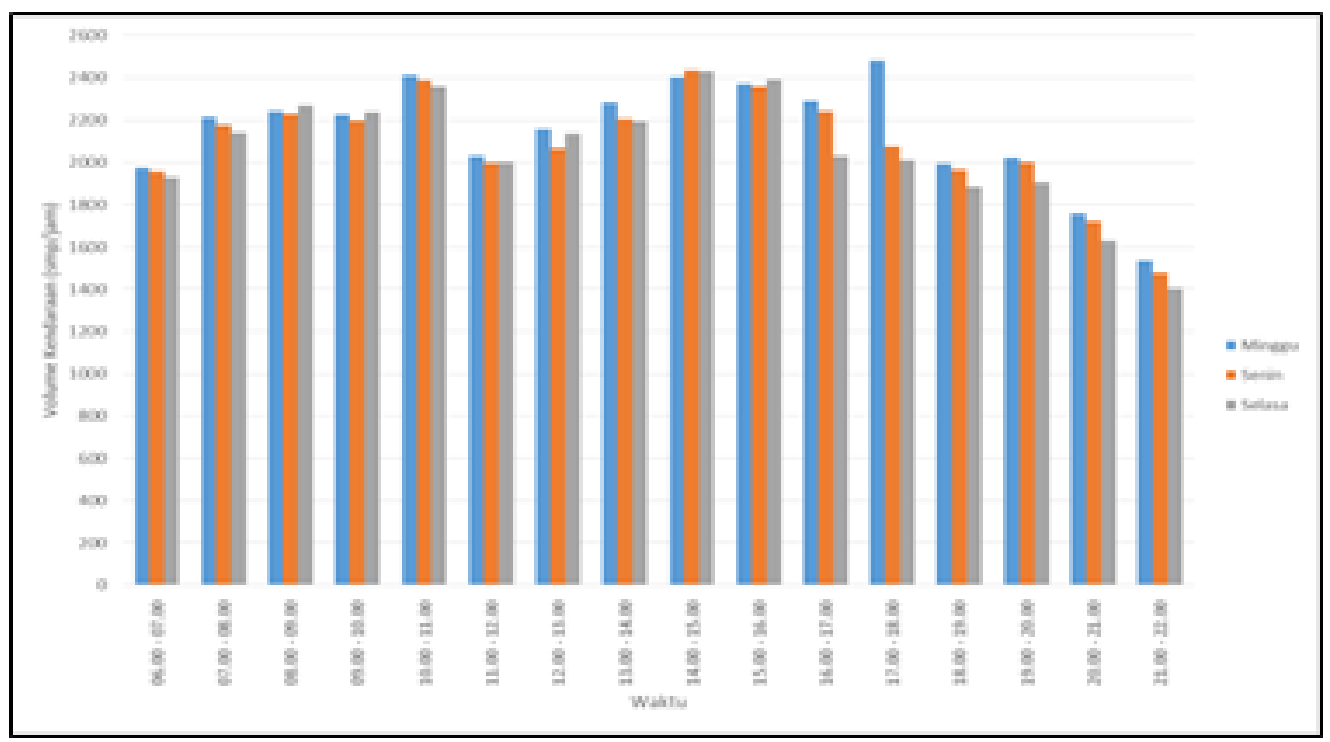

Gambar 2. Grafik Hubungan Volume Kendaraan dengan Waktu di Jalan Raya Singosari Arah Lawang

Hasil pengamatan volume kendaraan tertinggi dan rata-rata harian pada ruas Jalan Raya Singosari arah Malang ditunjukkan pada Tabel 4 dan Tabel 5.

Tabel 4. Data Volume Kendaraan Tertinggi di Jalan Raya Singosari Arah Malang

\begin{tabular}{|c|c|c|c|c|c|}
\hline \multirow{2}{*}{ Hari } & \multirow{2}{*}{ Pukul } & \multicolumn{3}{|c|}{ Jumlah kendaraan (smp/jam) } & \multirow{2}{*}{$\begin{array}{c}\text { Volume Tertinggi } \\
\text { (smp/jam) }\end{array}$} \\
\hline & & MC & $\mathbf{L V}$ & HV & \\
\hline Minggu & $16.00-17.00$ & 801 & 1496 & 158,4 & 2455,4 \\
\hline Senin & $16.00-17.00$ & 810,75 & 1319 & 165,6 & 2295,35 \\
\hline Selasa & $15.00-16.00$ & 767,25 & 1407 & 165,6 & 2339,85 \\
\hline
\end{tabular}

Tabel 5. Data Volume Kendaraan Rata-rata Harian di Jalan Raya Singosari Arah Malang

\begin{tabular}{ccccc}
\hline \multirow{2}{*}{ Hari } & \multicolumn{2}{c}{ Jumlah kendaraan rata-rata harian } & (smp/jam) & Volume Rata-rata Har- \\
\cline { 2 - 4 } & MC & LV & HV & ian (smp/jam) \\
\hline Minggu & 526,81 & 1100,9 & 205,35 & 1833,03 \\
\hline Senin & 534,42 & 1133,6 & 207,45 & 1875,43 \\
\hline Selasa & 523,22 & 1146,3 & 199,5 & 1869,03 \\
\hline
\end{tabular}

Data volume kendaraan (smp/jam) ruas Jalan Raya Singosari Arah Malang ditunjukkan pada Gambar 3 


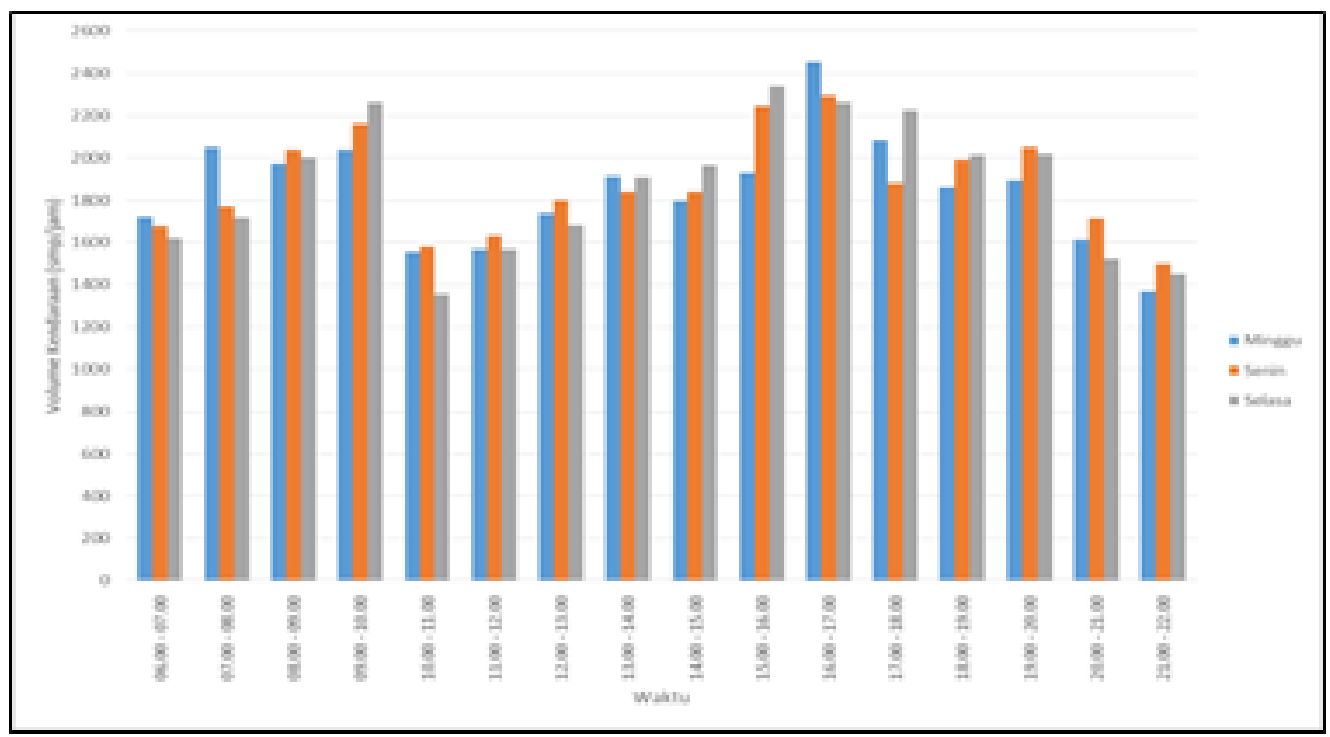

Gambar 3. Grafik Hubungan Volume Kendaraan dengan Waktu di Jalan Raya Singosari Arah Malang

\section{Kecepatan Kendaraan}

Hasil pengamatan kecepatan kendaraan tertinggi dan rata-rata harian pada ruas Jalan Raya Singosari arah Lawang ditunjukkan pada Tabel 6 dan Tabel 7 . kan oleh volume kendaraan yang tinggi pada jam puncak dan adanya traffic light yang beroperasi pada hari Senin dan Selasa. Traffic light mempengaruhi kecepatan kendaraan menjadi rendah karena kendaraan bersiap untuk ber-

Tabel 6. Data Kecepatan Tertinggi di Ruas Jalan Raya Singosari Arah Lawang

\begin{tabular}{ccccc}
\hline \multirow{2}{*}{ Hari } & \multirow{2}{*}{ Pukul } & Waktu Tempuh & Kecepatan & Kecepatan Tertinggi \\
\cline { 3 - 5 } & & $(\mathbf{d t})$ & $\mathbf{( m / \mathbf { s } )}$ & $\mathbf{( \mathbf { k m } / \mathbf { j a m } )}$ \\
\hline Minggu & $21.00-22.00$ & 3,74 & 6,69 & 24,10 \\
\hline Senin & $21.00-22.00$ & 3,60 & 6,95 & 25,05 \\
\hline Selasa & $21.00-22.00$ & 3,42 & 7,31 & 26,31 \\
\hline
\end{tabular}

Tabel 7. Data Kecepatan Rata-rata Harian di Ruas Jalan Raya Singosari Arah Lawang

\begin{tabular}{ccccc}
\hline \multirow{2}{*}{ Hari } & Panjang Penggal & $\begin{array}{c}\text { Waktu Tempuh } \\
\text { Rata-rata }\end{array}$ & $\begin{array}{c}\text { Kecepatan } \\
\text { Rata-rata }\end{array}$ & $\begin{array}{c}\text { Kecepatan Rata-rata } \\
\text { Harian }\end{array}$ \\
\cline { 2 - 5 } & $\mathbf{( m )}$ & $\mathbf{( d t )}$ & $\mathbf{( m / s )}$ & $\mathbf{( k m / j a m )}$ \\
\hline Minggu & 25 & 4,94 & 5,11 & 18,40 \\
\hline Senin & 25 & 4,78 & 5,28 & 19,01 \\
\hline Selasa & 25 & 4,71 & 5,38 & 19,37 \\
\hline
\end{tabular}

Kecepatan kendaraan terendah terjadi pada hari Minggu pukul 17.00 - 18.00 sebesar 15,91 $\mathrm{km} / \mathrm{jam}$. Kecepatan rendah tersebut disebab- henti sesaat pada saat lampu merah. Data kecepatan kendaraan ruas Jalan Raya Singosari Arah Lawang ditunjukkan pada Gambar 4. 


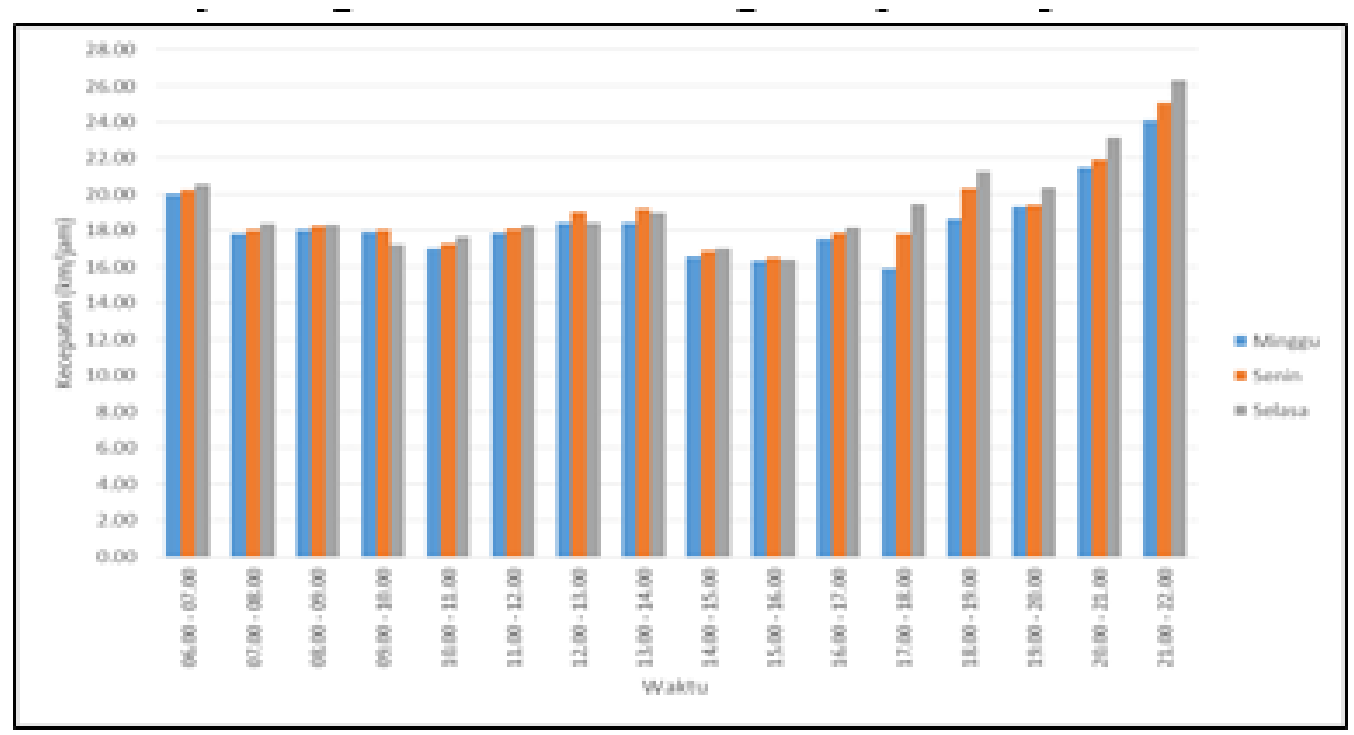

Gambar 4. Grafik Hubungan Kecepatan Kendaraan dengan Waktu di Ruas Jalan Raya Singosari Arah Lawang

Hasil pengamatan kecepatan kendaraan tertinggi dan rata-rata harian pada ruas Jalan Raya Singosari arah Malang ditunjukkan pada Tabel 8 dan Tabel 9 akan menjadi kosong sesaat. Kemudian saat lampu hijau, kendaraan akan melintas dengan kecepatan tinggi karena volume kendaraan rendah. Sedangkan kecepatan kendaraan ren-

Tabel 8. Data Kecepatan Tertinggi di Ruas Jalan Raya Singosari Arah Malang

\begin{tabular}{ccccc}
\hline \multirow{2}{*}{ Hari } & \multirow{2}{*}{ Pukul } & Waktu Tempuh & Kecepatan & Kecepatan Tertinggi \\
\cline { 3 - 5 } & & $\mathbf{( d t )}$ & $\mathbf{( m / \mathbf { s } )}$ & $\mathbf{( k m / j a m )}$ \\
\hline Minggu & $21.00-22.00$ & 3,11 & 8,03 & 28,91 \\
\hline Senin & $11.00-12.00$ & 3,26 & 7,66 & 27,58 \\
\hline Selasa & $11.00-12.00$ & 2,81 & 8,87 & 31,96 \\
\hline
\end{tabular}

Tabel 9. Data Kecepatan Rata-rata Harian di Ruas Jalan Raya Singosari Arah Malang

\begin{tabular}{ccccc}
\hline \multirow{2}{*}{ Hari } & Panjang Penggal & $\begin{array}{c}\text { Waktu Tempuh } \\
\text { Rata-rata }\end{array}$ & $\begin{array}{c}\text { Kecepatan } \\
\text { Rata-rata }\end{array}$ & $\begin{array}{c}\text { Kecepatan Rata-rata } \\
\text { Harian }\end{array}$ \\
\cline { 2 - 5 } & $\mathbf{( m )}$ & $\mathbf{( d t )}$ & $\mathbf{( m / s )}$ & $\mathbf{( k m / j a m )}$ \\
\hline Minggu & 25 & 4,12 & 6,04 & 21,76 \\
\hline Senin & 25 & 4,20 & 5,91 & 21,29 \\
\hline Selasa & 25 & 4,13 & 6,08 & 21,89 \\
\hline
\end{tabular}

Kecepatan kendaraan tertinggi terjadi pada hari Selasa pukul 11.00 - 12.00 sebesar $31,96 \mathrm{~km} / \mathrm{jam}$. Kecepatan tertinggi terjadi pada hari Senin dan Selasa pada pukul 11.00 -

12.00 bisa disebabkan oleh faktor lain seperti adanya traffic light yang beroperasi pada hari tersebut. Pada saat lampu merah, jalan dah pada pukul 09.00 - 10.00 bisa disebabkan oleh hambatan samping akibat aktivitas Pasar Singosari saat pagi hari di sisi jalan meliputi parkir dan banyaknya kendaraan yang berhenti terutama angkutan umum. Data kecepatan kendaraan (km/jam) ruas Jalan Raya Singosari Arah Malang ditunjukkan pada Gambar 5. 


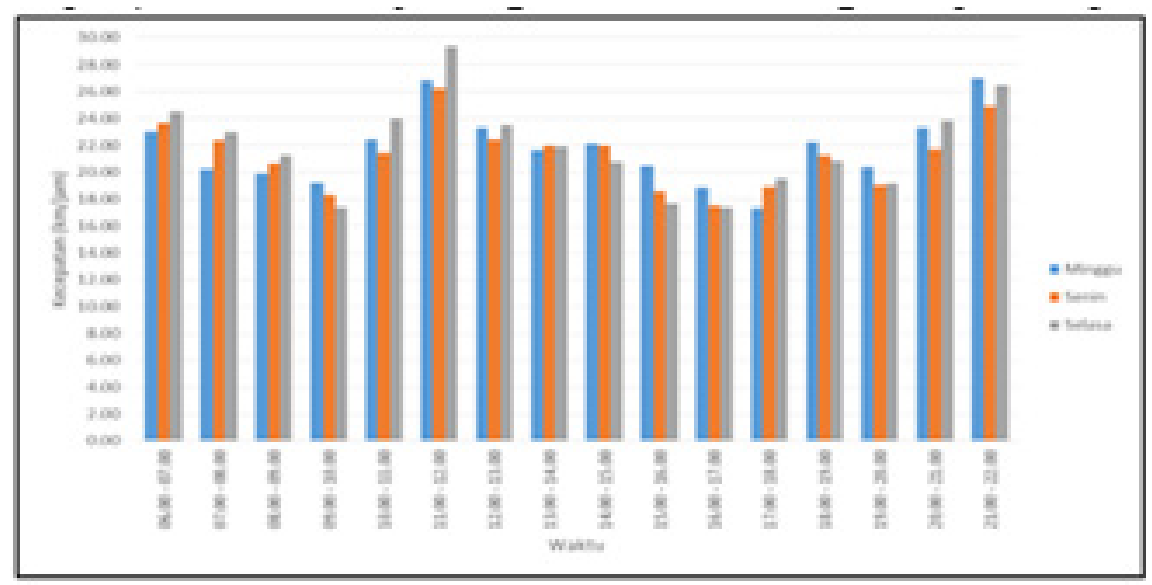

\section{Gambar 5. Grafik Hubungan Kecepatan Kendaraan dengan Waktu di Ruas Jalan Raya Singosari Arah Malang}

\section{Kepadatan Lalu Lintas}

Hasil pengamatan kepadatan tertinggi pada ruas Jalan Raya Singosari arah Lawang ditunjukkan pada Tabel 10. ggu. Dengan kepadatan tertinggi pada hari Minggu maka ruang bebas antar kendaraan menjadi lebih kecil sehingga kecepatan menjadi rendah, terbukti dengan kecepa-

Tabel 10. Data Kepadatan Tertinggi di Ruas Jalan Raya Singosari Arah Lawang

\begin{tabular}{ccccc}
\hline \multirow{2}{*}{ Hari } & \multirow{2}{*}{ Pukul } & Volume & Kecepatan & Kepadatan Tertinggi \\
\cline { 2 - 5 } & & $\mathbf{( s m p / j a m )}$ & $\mathbf{( k m / j a m )}$ & $\mathbf{( s m p / k m )}$ \\
\hline Minggu & $16.30-17.30$ & 2561,8 & 15,99 & 160,18 \\
\hline Senin & $14.30-15.30$ & 2434,2 & 16,25 & 149,79 \\
\hline Selasa & $14.30-15.30$ & 2432,25 & 16,26 & 149,55 \\
\hline
\end{tabular}

Kepadatan rata-rata harian tertinggi terjadi pada hari Minggu sebesar 124,83 smp/ $\mathrm{km}$ disebabkan oleh volume kendaraan tertinggi yang juga terjadi pada hari Min- tan terendah terjadi pada hari Minggu pula. Data kepadatan di ruas Jalan Raya Singosari Arah Lawang ditunjukkan pada Gambar 6.

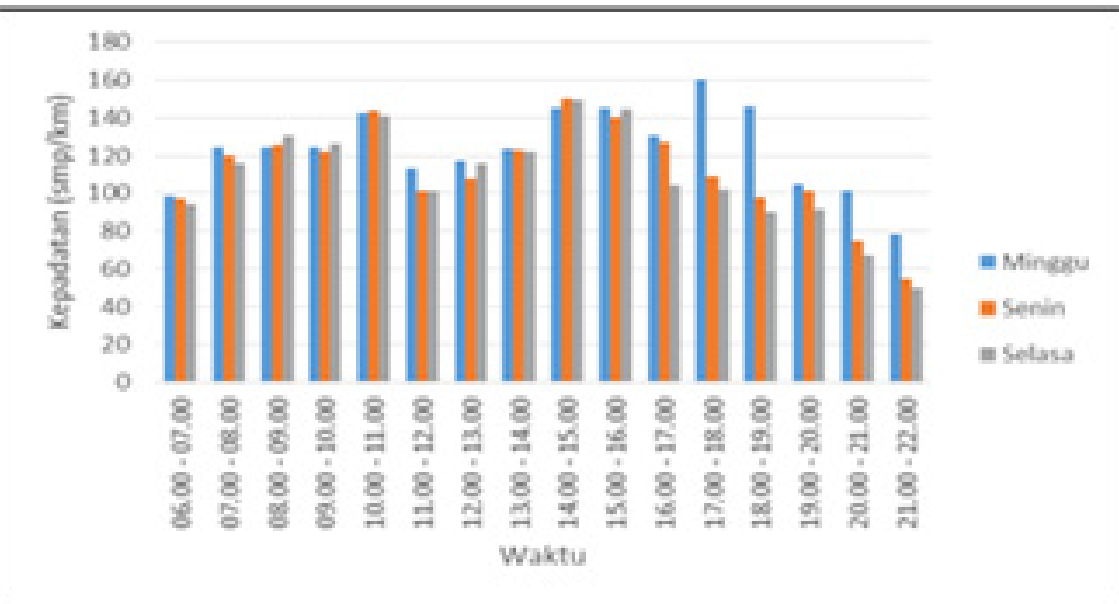

Gambar 6. Grafik Hubungan Kepadatan dengan Waktu di Ruas Jalan Raya Singosari Arah Lawang 
Hasil pengamatan kepadatan ter- rendah disebabkan oleh hambatan samptinggi pada ruas Jalan Raya Singosari ing yang terjadi di sisi jalan karena aktivitas arah Malang ditunjukkan pada Tabel 11. Pasar Singosari yang menggunakan badan

Tabel 11. Data Kepadatan Tertinggi di Ruas Jalan Raya Singosari Arah Malang

\begin{tabular}{ccccc}
\hline \multirow{2}{*}{ Hari } & \multirow{2}{*}{ Pukul } & Volume & Kecepatan & Kepadatan \\
\cline { 2 - 5 } & & $\mathbf{( s m p / j a m )}$ & $\mathbf{( k m / j a m )}$ & Tertinggi $(\mathbf{s m p} / \mathbf{k m})$ \\
\hline Minggu & $17.00-18.00$ & 2455,4 & 17,77 & 141,68 \\
\hline Senin & $16.00-17.00$ & 2295,35 & 17,46 & 131,41 \\
\hline Selasa & $15.00-16.00$ & 2325,9 & 17,21 & 135,10 \\
\hline
\end{tabular}

Dengan kepadatan tertinggi pada hari jalan sebagai lahan parkir dan banyak kendSenin maka ruang bebas antar kendaraan menjadi lebih kecil sehingga kecepatan menjadi rendah, terbukti dengan kecepatan terendah terjadi pada hari Senin. Kecepatan yang Arah Malang ditunjukkan pada Gambar 7.

araan berhenti terutama angkutan umum. Data kepadatan di ruas Jalan Raya Singosari

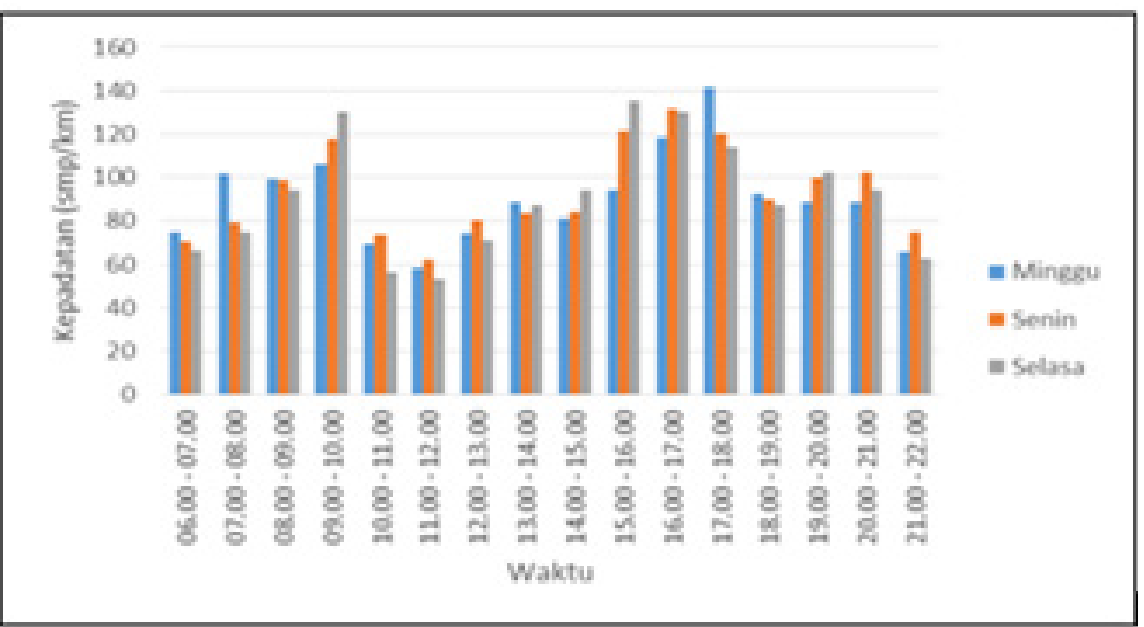

Gambar 7. Grafik Hubungan Kepadatan dengan Waktu di Ruas Jalan Raya Singosari Arah Malang

Hambatan Samping

Hasil pengamatan jumlah hambatan samping tertinggi yang terjadi di ruas Jalan Raya Singosari STA 78 arah Lawang ditunjukkan pada Tabel 12.
Hasil pengamatan jumlah hambatan samping tertinggi yang terjadi di ruas Jalan Raya Singosari STA 78 arah Malang ditunjukkan pada Tabel 13.

Tabel 12. Data Hambatan Samping Tertinggi di Ruas Jalan Singosari 78 Arah Lawang

\begin{tabular}{lccc}
\hline \multicolumn{1}{c}{ Tipe Kejadian } & Faktor Bobot & Frekuensi Kejadian per jam & Frekuensi Bobot \\
\hline Pejalan Kaki & 0,5 & 427 & 213,5 \\
\hline Kendaraan Berhenti & 1 & 177 & 177 \\
\hline Kendaraan Masuk dan & 0,7 & 763 & 534,1 \\
\hline keluar & & & \\
\hline Kendaraan lambat & 0,4 & 187 & 74,8 \\
\hline & Total & 1554 & 999,4 \\
\hline
\end{tabular}


Tabel 13 Data Hambatan Samping Tertinggi di Ruas Jalan Singosari STA 78 Arah Malang

\begin{tabular}{|c|c|c|c|}
\hline Tipe Kejadian & Faktor Bobot & Frekuensi Kejadian & Frekuensi Bobot \\
\hline Pejalan Kaki & 0,5 & 489 & 244,5 \\
\hline Kendaraan Berhenti & 1 & 282 & 282 \\
\hline Kendaraan Masuk dan keluar & 0,7 & 861 & 602.7 \\
\hline Kendaraan lambat & 0,4 & 263 & 105,2 \\
\hline Total & & 1185 & 1234,4 \\
\hline
\end{tabular}

Tingkat kelas hambatan di ruas Jalan Raya Singosari STA 78 arah Lawang dan arah Malang dengan jumlah kejadian berbobot per 200 meter per jam lebih dari 900 kejadian adalah VH (Very High).

\section{Kapasitas Jalan}

Hasil perhitungan kapasitas ruas Jalan Raya Singosari ditunjukkan pada Tabel 14. adalah 1,00. Sedangkan untuk ruas jalan arah Malang, nilai FCW adalah 0,92. Untuk jalan terbagi, peluang terjadi kecelakaan lebih kecil karena peluang untuk mendahului kendaraan lain lebih kecil, sehingga faktor penyesuaian kapasitas untuk pemisah arah jalan terbagi (FCSP) adalah 1,00. Ruas Jalan Raya Singosari arah Lawang tidak memiliki bahu jalan

\begin{tabular}{|c|c|c|c|c|c|c|}
\hline \multirow[b]{2}{*}{ Ruas Jalan } & \multirow[b]{2}{*}{$\begin{array}{c}\text { Kapasitas Dasar } \\
\text { Co (smp/jam) }\end{array}$} & \multicolumn{4}{|c|}{ Faktor Pengaruh Kapasitas } & \multirow[b]{2}{*}{$\begin{array}{c}\text { Kapasitas } \\
\text { C (smp/ } \\
\text { jam) }\end{array}$} \\
\hline & & $\begin{array}{l}\text { Lebar Jalur } \\
\text { (FCw) }\end{array}$ & $\begin{array}{c}\text { Pemisah } \\
\text { Arah (FCsp) }\end{array}$ & $\begin{array}{c}\text { Hambatan } \\
\text { Samping } \\
\text { (FCsf) } \\
\end{array}$ & $\begin{array}{c}\text { Ukuran } \\
\text { Kota } \\
\text { (FCcs) } \\
\end{array}$ & \\
\hline Arah Lawang & 3300 & 1,00 & 1,00 & 0,84 & 0,86 & 2383,9 \\
\hline Arah Malang & 3300 & 0,92 & 1,00 & 0,84 & 0,86 & 2193,2 \\
\hline
\end{tabular}

Nilai kapasitas dasar untuk jalan perkotaan dengan tipe jalan 4 lajur 2 arah terbagi (4/2D) adalah $1650 \mathrm{smp} /$ jam per lajur (MKJI, 1970). Nilai kapasitas dasar (C0) untuk masing-masing ruas Jalan Raya Singosari arah Lawang dan arah Malang adalah $1650 \mathrm{smp} /$ jam x $2=$ 3300 smp/jam. Jalan Raya Singosari memiliki lebar jalan per lajur sebesar 3,5 m. Akibat adanya parkir di badan jalan pada ruas jalan arah Malang, lebar efektif jalan berkurang menjadi 4,5 m, sehingga lebar efektif per lajur kurang dari 3 m. Faktor penyesuaian kapasitas lebar jalan (FCW) untuk Jalan Raya Singosari arah Lawang dengan tipe jalan 4 lajur terbagi dengan lebar jalan per lajurnya adalah 3,5 m dengan kelas hambatan samping adalah $\mathrm{VH}$ (Very High) yang didapatkan dari hasil survei jumlah hambatan samping. Nilai FCSF kedua ruas jalan adalah 0,84. Ruas Jalan Raya Singosari berada di Kecamatan Singosari dengan jumlah penduduk mencapai 174.602 jiwa (BPS Kabupaten Malang, 2017), maka faktor penyesuaian ukuran kota (FCCS) adalah 0,86.

Menurut hasil survei, volume kendaraan tertinggi pada kedua ruas jalan sebesar 2483,3 smp/jam dan 2339,85 smp/jam sudah melebihi kapasitas jalan yang tersedia.

\section{Derajat Kejenuhan dan Tingkat Pelayanan}

Hasil perhitungan derajat kejenuhan dan tingkat pelayanan rata-rata harian dan tertinggi pada ruas Jalan Raya Singosari ditunjukkan pada Tabel 15 dan Tabel 16. 
Tabel 15. Data Derajat Kejenuhan dan Tingkat Pelayanan Rata-rata Harian Ruas Jalan Raya Singosari

\begin{tabular}{|c|c|c|c|c|c|}
\hline $\begin{array}{l}\text { Ruas } \\
\text { Jalan }\end{array}$ & Hari & $\begin{array}{c}\text { Volume Rata-rata } Q \\
\text { (smp/jam) }\end{array}$ & $\begin{array}{c}\text { Kapasitas C } \\
\text { (smp/jam) }\end{array}$ & $\mathrm{Ds}=\mathrm{Q} / \mathrm{C}$ & $\begin{array}{c}\text { Tingkat Pelayanan } \\
\text { Rata-rata Harian }\end{array}$ \\
\hline \multirow{3}{*}{$\begin{array}{c}\text { Arah } \\
\text { Lawang }\end{array}$} & Minggu & 2149,85 & \multirow{3}{*}{2383,9} & 0,90 & $\mathrm{E}$ \\
\hline & Senin & 2088,89 & & 0,87 & $\mathrm{E}$ \\
\hline & Selasa & 2055,82 & & 0,86 & $\mathrm{E}$ \\
\hline \multirow{3}{*}{$\begin{array}{c}\text { Arah } \\
\text { Malang }\end{array}$} & Minggu & 1833,03 & \multirow{3}{*}{2193,2} & 0,83 & $\mathrm{D}$ \\
\hline & Senin & 1875,43 & & 0,85 & $\mathrm{E}$ \\
\hline & Selasa & 1869,03 & & 0,85 & $\mathrm{E}$ \\
\hline
\end{tabular}

Tabel 16. Data Derajat Kejenuhan Tertinggi dan Tingkat Pelayanan Terendah Ruas Jalan Raya Singosari

\begin{tabular}{ccccccc}
\hline \multirow{2}{*}{ Ruas Jalan } & Hari & Pukul & $\begin{array}{c}\text { Volume } \\
\text { Tertinggi Q } \\
\text { (smp/jam) }\end{array}$ & $\begin{array}{c}\text { Kapasitas } \\
\mathbf{C}(\mathbf{s m p} / \\
\text { jam) }\end{array}$ & Ds = Q/C & $\begin{array}{c}\text { Tingkat } \\
\text { Pelayanan }\end{array}$ \\
\hline \multirow{3}{*}{ Arah Lawang } & Minggu & $16.30-17.30$ & 2561,8 & & 1,07 & $\mathrm{~F}$ \\
\cline { 2 - 7 } & Senin & $14.30-15.30$ & 2434,2 & 2383,9 & 1,02 & $\mathrm{~F}$ \\
\cline { 2 - 7 } & Selasa & $14.30-15.30$ & 2432,25 & & 1,02 & $\mathrm{~F}$ \\
\hline \multirow{3}{*}{ Arah Malang } & Minggu & $16.00-17.00$ & 2455,4 & & 1,11 & $\mathrm{~F}$ \\
\cline { 2 - 7 } & Senin & $16.00-17.00$ & 2295,35 & 2193,2 & 1,04 & $\mathrm{~F}$ \\
\cline { 2 - 7 } & Selasa & $15.00-16.00$ & 2339,85 & & 1,06 & $\mathrm{~F}$ \\
\hline
\end{tabular}

Volume harian pada ruas jalan arah Lawang dan arah Malang sudah melebihi kapasitas jalan yang tersedia, sehingga menyebabkan nilai derajat kejenuhan tinggi. Menurut MKJI (1997), angka derajat kejenuhan lebih dari 0,75 menunjukkan arus lalu lintas jenuh dan diperlukan penanganan pada ruas jalan tersebut. Nilai DS tertinggi untuk kedua ruas jalan yang diperoleh dari hasil survei sudah melebihi nilai standar DS dari MKJI (1970) sebesar 0,75 menunjukkan bahwa kedua ruas jalan tersebut memerlukan penanganan lebih lanjut.

\section{Alternatif Peningkatan Tingkat Pelayanan}

Alternatif untuk meningkatkan tingkat pelayanan pada ruas Jalan Raya Singosari sangat dibutuhkan karena dari hasil pengamatan menunjukkan tingkat pelayanan kedua ruas jalan pada kondisi volume puncak berada di kelas F. Perencanaan solusi alternatif yang bisa dilakukan pada kedua ruas jalan tersebut yaitu pelebaran jalan dan penerapan lalu lintas tanpa hambatan samping.

Pelebaran jalan dilakukan dalam bentuk penambahan lajur yang dapat meningkatkan kapasitas jalan untuk menampung volume kendaraan. Lajur ditambahkan dengan memotong sebagian lahan samping jalan untuk difungsikan sebagai lajur baru, sehingga jumlah lajur untuk tiap arah menjadi 3 lajur. Hasil perhitungan kapasitas jalan dengan pelebaran jalan ditunjukkan pada Tabel 17. 
Tabel 17. Data Kapasitas Ruas Jalan Raya Singosari dengan Pelebaran Jalan

\begin{tabular}{|c|c|c|c|c|c|c|}
\hline \multirow[b]{2}{*}{ Ruas Jalan } & \multirow[b]{2}{*}{$\begin{array}{c}\text { Kapasitas } \\
\text { Dasar Co } \\
\text { (smp/jam) }\end{array}$} & \multicolumn{4}{|c|}{ Faktor Pengaruh Kapasitas } & \multirow[b]{2}{*}{$\begin{array}{c}\text { Kapasitas } \\
\text { C (smp/ } \\
\text { jam) }\end{array}$} \\
\hline & & $\begin{array}{l}\text { Lebar Jalur } \\
\text { (FCw) }\end{array}$ & $\begin{array}{c}\text { Pemisah } \\
\text { Arah (FCsp) }\end{array}$ & $\begin{array}{c}\text { Hambatan } \\
\text { Samping } \\
\text { (FCsf) } \\
\end{array}$ & $\begin{array}{c}\text { Ukuran } \\
\text { Kota } \\
\text { (FCcs) }\end{array}$ & \\
\hline Arah Lawang & 4950 & 1,00 & 1,00 & 0,84 & 0,86 & 3575,88 \\
\hline Arah Malang & 4950 & 0,92 & 1,00 & 0,84 & 0,86 & 3289,80 \\
\hline
\end{tabular}

Tabel 18. Data Derajat Kejenuhan dan Tingkat Pelayanan dengan Pelebaran Jalan pada Jalan Raya Singosari

\begin{tabular}{cccccc}
\hline Ruas Jalan & Hari & $\begin{array}{c}\text { Volume Rata-rata } \\
\text { Harian }(\mathbf{s m p} / \mathbf{j a m})\end{array}$ & $\begin{array}{c}\text { Kapasitas } \\
(\mathbf{s m p} / \mathbf{j a m})\end{array}$ & Ds $=\mathbf{Q} / \mathbf{C}$ & Tingkat Pelayanan \\
\hline \multirow{2}{*}{$\begin{array}{c}\text { Arah La- } \\
\text { wang }\end{array}$} & Minggu & 2149,85 & & 0,60 & $\mathrm{C}$ \\
\cline { 2 - 6 } & Senin & 2088,89 & 3577,88 & 0,58 & $\mathrm{C}$ \\
\cline { 2 - 6 } & Selasa & 2055,82 & & 0,57 & $\mathrm{C}$ \\
\hline \multirow{2}{*}{$\begin{array}{c}\text { Arah } \\
\text { Malang }\end{array}$} & Minggu & 1833,03 & & 0,55 & $\mathrm{C}$ \\
\cline { 2 - 6 } & Senin & 1875,43 & 3289,80 & 0,57 & $\mathrm{C}$ \\
\cline { 2 - 6 } & Selasa & 1869,03 & & 0,56 & $\mathrm{C}$ \\
\hline
\end{tabular}

Kapasitas jalan meningkat dari kapasitas aktual sebesar 2383,9 smp/jam dan 2193,2 smp/jam menjadi 3575,88 smp/jam dan 3289,80 smp/jam. Angka derajat kejenuhan menurun dan tingkat pelayanan menjadi lebih baik seperti yang ditunjukkan pada Tabel 18 .

Dari hasil perhitungan, Nilai DS kedua ruas jalan yang diperoleh dari hasil perhitungan tidak melebihi standar nilai DS dari MKJI (1970) sebesar 0,75. Tingkat pelayanan untuk kedua ruas jalan berada di kelas C.

Perencanaan lalu lintas tanpa hambatan samping dilakukan dengan menggunakan lebar jalan efektif sesungguhnya tanpa pengaruh hambatan samping yang terjadi. Dari hasil perhitungan dapat diketahui kinerja jalan sesungguhnya tanpa adanya hambatan samping yang dapat dilakukan dengan beberapa usaha seperti: (1) Pengelolaan parkir di lahan samping jalan dan pelarangan parkir menggunakan bahu jalan dan lebar efektif jalan; (2)
Perbaikan pagar pada median jalan sehingga penyeberang jalan tidak dapat menyeberang di ruas jalan sehingga harus menggunakan Jembatan Penyeberangan Orang (JPO) yang sudah tersedia; (3) Perbaikan halte untuk angkutan umum dan pemberian sanksi bagi angkutan umum yang berhenti tidak pada halte; (4) Pemberian tanda dilarang berhenti di sepanjang ruas Jalan Raya Singosari terutama di depan Pasar Singosari; (5) Perbaikan trotoar bagi pejalan kaki sehingga pejalan kaki merasa nyaman dan tidak berjalan di badan jalan.

Hasil perhitungan kapasitas jalan tanpa adanya hambatan samping melalui usahausaha tersebut ditunjukkan pada Tabel 19.

Kapasitas jalan menjadi meningkat dari kapasitas aktual sebesar 2383,9 smp/jam dan 2193,2 smp/jam menjadi 2724,48 smp/jam. Dari peningkatan kapasitas jalan tersebut, angka derajat kejenuhan menurun dan tingkat pelayanan menjadi lebih baik ditunjukkan pada Tabel 20 . 
Tabel 19. Data Kapasitas Ruas Jalan Raya Singosari dengan Penerapan Jalan Tanpa Hambatan Samping

\begin{tabular}{ccccccc}
\hline \multirow{2}{*}{$\begin{array}{c}\text { Juas } \\
\text { Jalan }\end{array}$} & $\begin{array}{c}\text { Kapasitas } \\
\text { Dasar Co } \\
\text { (smp/jam) }\end{array}$ & $\begin{array}{c}\text { Lebar Jalur } \\
\text { (FCw) }\end{array}$ & $\begin{array}{c}\text { Pemisah Arah } \\
\text { (FCsp) }\end{array}$ & $\begin{array}{c}\text { Hambatan } \\
\text { Samping } \\
\text { (FCsf) }\end{array}$ & $\begin{array}{c}\text { Ukuran } \\
\text { Kota } \\
\text { (FCcs) }\end{array}$ & $\begin{array}{c}\text { Kapasitas C } \\
\text { (smp/jam) }\end{array}$ \\
\hline $\begin{array}{c}\text { Arah La- } \\
\text { wang }\end{array}$ & 3300 & 1,00 & 1,00 & 0,96 & 0,86 & 2724,48 \\
\hline $\begin{array}{c}\text { Arah } \\
\text { Malang }\end{array}$ & 3300 & 1,00 & 1,00 & 0,96 & 0,86 & 2724,48 \\
\hline
\end{tabular}

Tabel 20. Data Derajat Kejenuhan dan Tingkat Pelayanan Ruas pada Jalan Raya Singosari dengan Penerapan Jalan Tanpa Hambatan Samping

\begin{tabular}{cccccc}
\hline \multirow{2}{*}{ Ruas Jalan } & Hari & $\begin{array}{c}\text { Volume Harian } \\
(\mathbf{s m p} / \mathbf{j a m})\end{array}$ & $\begin{array}{c}\text { Kapasitas } \\
(\mathbf{s m p} / \mathbf{j a m})\end{array}$ & Ds $=\mathbf{Q} / \mathbf{C}$ & Tingkat Pelayanan \\
\hline \multirow{3}{*}{ Arah Lawang } & Minggu & 2149,85 & & 0,78 & $\mathrm{D}$ \\
\cline { 2 - 6 } & Senin & 2088,89 & 2724,48 & 0,76 & $\mathrm{D}$ \\
\cline { 2 - 6 } & Selasa & 2055,82 & & 0,75 & $\mathrm{D}$ \\
\hline \multirow{3}{*}{ Arah Malang } & Minggu & 1833,03 & & 0,67 & $\mathrm{C}$ \\
\cline { 2 - 6 } & Senin & 1875,43 & 2724,48 & 0,68 & $\mathrm{C}$ \\
\cline { 2 - 6 } & Selasa & 1869,03 & & 0,68 & $\mathrm{C}$ \\
\hline
\end{tabular}

Dari hasil perhitungan, Nilai DS ruas jalan arah Lawang masih melebihi melebihi standar nilai DS dari MKJI (1970) sebesar 0,75. Tingkat pelayanan untuk kedua ruas jalan berada di kelas $\mathrm{C}$ dan $\mathrm{D}$.

\section{SIMPULAN}

Berdasarkan hasil penelitian dan pembahasan, maka dapat disimpulkan sebagai berikut: (1) Karakteristik arus lalu lintas pada Jalan Raya Singosari arah Lawang, volume kendaraan tertinggi yaitu pada hari Minggu pukul 16.30 - 17.30 mencapai $2561,8 \mathrm{smp} /$ jam. Kecepatan tertinggi terjadi pada hari Selasa pukul 21.00 - 22.00 mencapai $26,31 \mathrm{~km} /$ jam dengan kecepatan harian rata-rata mencapai 19,37 km/jam. Kepadatan terbesar terjadi pada hari Minggu pukul 16.30 - 17.30 mencapai $151,84 \mathrm{smp} / \mathrm{km}$; (2) Karakteristik arus lalu lintas pada Jalan Raya Singosari arah Malang, volume kendaraan tertinggi yaitu pada hari Minggu pukul 16.00 - 17.00 mencapai 2455,4 smp/jam. Kecepatan tertinggi terjadi pada hari Selasa pukul 11.00 - 12.00 mencapai 31,96 $\mathrm{km} / \mathrm{jam}$ dengan kecepatan harian rata-rata mencapai 21,89 km/jam. Kepadatan terbesar terjadi pada hari Minggu pukul 16.15 - 17.15 mencapai 152,4 smp/km; (3) Tingkat pelayanan rata-rata harian untuk kedua ruas jalan berada di rentang D dan E. Dengan tingkat pelayanan pada jam puncak berada di kelas F; (4) Alternatif pelebaran jalan dalam bentuk penambahan 1 lajur pada kedua ruas jalan dapat menurunkan nilai derajat kejenuhan dari 0,90 menjadi 0,60 sehingga tingkat pelayanan menjadi lebih baik di kelas $\mathrm{C}$, sedangkan alternatif penerapan lalu lintas tanpa hambatan samping dapat menurunkan derajat kejenuhan 
dari 0,90 menjadi 0,78 sehingga tingkat pelayanan menjadi lebih baik di rentang kelas $\mathrm{C}$ dan D.

\section{DAFTAR RUJUKAN}

Ansyori, A.A. 2003. Rekayasa Jalan Raya. Malang: Universitas Muhammadiyah. Di rektorat Jenderal Bina Marga. 1997. Manu al Kapasitas Jalan Indonesia (MKJI). Ja karta: Departemen Pekerjaan Umum. Hadi, S. 2016. Ruas Lawang-Singosari, Malang Masih Jadi Perhatian Utama. Surya Malang (online), diakses 30 Maret 2018. Keputusan Gubernur Jawa Timur Nomor 188 Tahun 2016 tentang Penetepan Ruasruas Jalan Menurut Statusnya Sebagai Ja lan Provinsi. Binamarga (online), (http:// binamarga.jatimprov.go.id), diakses 20 Februari 2018.

Oglesby, C.H.; Hicks, R.G. 1999. Teknik Jalan Raya (Jilid 1). Terjemahan Purwo Setianto. Jakarta: Gramedia. Tanpa tahun.
Peraturan Menteri Perhubungan Nomor 14 Ta hun 2006 tentang Manajemen dan Rekaya sa Lalu Lintas di Jalan. Departemen Per hubungan (online), (http://hubdat.dephub. go.id), diakses 5 Maret 2018.

Putra, C.A.P.; Purbanto, I.G.R.; \& Suparsa, I.G.P. 2011. Analisis Kinerja Ruas Jalan Raya Sukawati Akibat Bangkitan Perger akan dari Pasar Seni Sukawati. Jurnal Ilmi ah Elektronik Infrastruktur Teknik Sipil. Dari http://ojs.unud.ac.id/index.php/jieits/ article/view/4386.

Setyawan. 2004. Pengaruh Kegiatan Pejalan Kaki Karyawan PT Maspion Terhadap Kinerja Lalu Lintas Ruas Jalan Waru-Gem pol. Tesis tidak diterbitkan, Malang: Pas casarjana Universitas Brawijaya Malang. Yunianta, A. 2006. Pengaruh Manuver Kenda raan Parkir Badan Jalan Terhadap Karak teristik Lalu Lintas di Jalan Diponegoro Yogyakarta. Tesis tidak diterbitkan, Yogya karta: Pascasarjana Universitas Dipone goro. 